\title{
PENGARUH PENDIDIKAN TEMAN SEBAYA (PEER EDUCATION) TERHADAP PERILAKU REMAJA PUTRI YANG MENDERITA ANEMIA DI MADRASAH STANAWIYAH ISLAMIYAH JL.SULUH 71 KOTA MEDAN TAHUN 2018
}

\author{
Raden Roro Siti Hatati Surjantini ${ }^{1}$, Hanna Sriyanti Saragih ${ }^{2}$ \\ ${ }^{1,2}$ Lecturer of Midwifery Department of Medan Health Polytechnic of Ministry of Health
}

\begin{abstract}
Young women are one group that is prone to anemia. Therefore, the target of nutritional anemia prevention programs has been developed to reach junior high school, high school and equivalent girls, and women outside of school as a strategic effort in an effort to break the cycle of nutrition problems. Even so, the prevalence of anemia among young women was still high. Data from the Ministry of Health in 2005 showed $26.50 \%$ of anemia in young women and $26.9 \%$ in fertiled age women. This indicated that anemia was still be a health problem in Indonesia. This type of research is a quasi-experimental one-group pre-test post-test design to determine the influence of Peer Education on the behavior of young women who suffer from anemia in Madrasah Stanawiyah Islamiyah on Jl. Suluh 71 Medan City in 2018. Research instruments using a questionnaire. The sample chosen in this study was the student of Madrasah Tsanawiyah Islamiyah Jl. Suluh 71 Kota Medan. The statistical test used was the t-test (independent-t test) to test for differences in the average $\mathrm{Hb}$ level of the study start and increase in $\mathrm{Hb}$ levels after administration in both groups. Based on the results obtained, it can be concluded that there was an influence of peer education (Peer Education) on the behavior of young women who suffer from anemia in Madrasah Stanawiyah Islamiyah Jl.Suluh 71 Kota Medan Kota in 2018. The average $\mathrm{Hb}$ level of subjects increased by 2, 13 after being given an intervention. The average score of subject behavior assessment increased by 34.33 after being given intervention. Expected for students in Madrasah Stanawiyah Islamiyah Jl.Suluh 71 Kota Medan Kota in 2018 in order to get used to eat foods that contain lots of iron which serves to increase hemoglobin levels in the blood thus inhibiting anemia.
\end{abstract}

Kata kunci : $\quad$ Peer Education, Adolescent, Anemia

\section{LATAR BELAKANG}

Anemia merupakan masalah medik yang paling sering dijumpai di seluruh dunia, di samping sebagai masalah kesehatan utama masyarakat, terutama di negara berkembang. ${ }^{1}$ World Health Organization (2) menyebutkan bahwa banyakmasalah gizi pada remaja masih terabaikan disebabkan karena masih banyaknya faktor-faktor yang belum diketahui, padahal remaja merupakan sumber daya manusia yang harus dilindungi karena potensinya yang sangat besar dalam upaya pembangunan kualitas bangsa. Anemia akibat kekurangan zat besi (Fe) juga merupakan salah satu masalah gizi utama di Asia termasuk di Indonesia. Pada anak usia sekolah, prevalensi anemia tertinggi ditemukan di Asia Tenggara dengan perkiraan sekitar $60 \%$ anak mengalami anemia. (3)

Prevalensi Anemia di Indonesia, berdasarkan data Riset Kesehatan Dasar (Riskesdas, 2013) masih dijumpai pada anak usia 5-14 tahun sebesar 26,4\%, Berbagai survei anemia pada remaja (anaksekolah) di Indonesia, prevalensi anemia berkisar antara 36\%-43\%. Angka ini tergolong masalah kesehatanmasyarakat karena prevalensinya
\40\%.Laporan berbagai studi di Indonesia memperlihatkan masih tingginya prevalensi anemia gizi pada remaja putri yang berkisar antara $20-50 \%$. Survei yang dilakukan oleh Gross et al(4) di Jakarta dan Yogyakarta melaporkan prevalensi anemia pada remaja sebesar $21,1 \%$. Penelitian Budiman5 menyebutkan dari sejumlah 545 orang sampel siswi SLTA di Kabupaten dan Kotamadya Sukabumi, Cirebon dan Tangerang Propinsi Jawa Barat sebanyak 40,4\%-nya menderita anemia.

Remaja putri memiliki risiko sepuluh kali lebih besar untuk menderita anemia dibandingkan dengan remaja putra. Hal ini dikarenakan remaja putri mengalami menstruasi setiap bulannya dan sedang dalam masa pertumbuhan sehingga membutuhkan asupan zat besi yang lebih banyak. Selain itu, ketidakseimbangan asupan zat gizi juga menjadi penyebab anemia pada remaja. Remaja putri biasanya sangat memperhatikan bentuk tubuh, sehingga banyak yang membatasi konsumsi makanan dan banyak pantangan terhadap makanan. ${ }^{5}$

Berbagai studi menunjukkan dampak negatif dari anemia akibat kekurangan zat gizi besi terhadap pertumbuhan dan perkembangan anak dan remaja. $(9,10)$ 
Anemia pada anak menyebabkan pertumbuhan dan perkembangan tidak optimal dan menurunkan prestasi belajar karena rasa cepat lelah, kehilangan gairah dan tidak dapat berkonsentrasi.(6) Sedangkan pada remaja penderita anemia, sebagai calon ibu yang akan melahirkan generasi penerus bangsa, anemia akan menyebabkan tingginya risiko untuk melahirkan bayi berat lahir rendah (BBLR) yang mempunyai kualitas hidup yang tidak optimal.(9,10)

Melihat dampak anemia yang sangat besar dalam menurunkan kualitas sumber daya manusia, maka sebaiknya penanggulangan anemia perlu dilakukan sejak dini, sebelum remaja putri menjadi ibu hamil, agar kondisi fisik remaja putri tersebut telah siap menjadi ibu yang sehat.(11) Remaja putri termasuk kelompok yang rawan terhadap anemia, hal ini disebabkan karena kebutuhan Fe pada wanita 3 kali lebih besar dari kebutuhan pria. Wanita mengalami menstruasi setiap bulannya yang berarti kehilangan darah secara rutin dalam jumlah cukup banyak, juga kebutuhan Fe meningkat karena untuk pertumbuhan fisik, mental dan intelektual, dan kurang mengkonsumsi sumber makanan hewani yang merupakan sumber Fe yang mudah diserap.

Pada studi pendahuluan yang dilakukan di Madrasah Stanawiyah Islamiyah Jl.Suluh 71 Kota Medan Kota Tahun 2018 dengan mewawancarai 50 orang siswi-siswi didapatkan pada umumnya siswi-siswi mengalami rasa pusing, pandangan terkadang terasa berkunang-kunang selama masa menstruasi. Berdasarkan latar belakang diatas maka dilakukan penelitian dengan judul Pengaruh Pendidikan Teman Sebaya (Peer Education) Terhadap Perilaku Remaja Putri Yang Menderita Anemia Di Madrasah Stanawiyah Islamiyah Jl.Suluh 71 Kota Medan Kota Tahun 2018.

\subsection{Perumusan masalah}

Berdasarkan latar belakang masalah di atas, maka dapat dirumuskan masalah penelitian yaitu "apakah ada pengaruh Pendidikan Teman Sebaya (Peer Education) Terhadap Perilaku Remaja Putri Yang Menderita Anemia Di Madrasah Stanawiyah Islamiyah Jl.Suluh 71 Kota Medan Kota Tahun 2018.

\subsection{Tujuan penelitian}

1.Tujuan umum : Untuk mengetahui pengaruh pendidikan teman sebaya

(Peer Education) terhadap perilaku remaja putri yang menderita anemia di Madrasah Stanawiyah Islamiyah Jl.Suluh 71 Kota Medan Kota Tahun 2018.

2. Tujuan khusus :

- Untuk mengetahui kadar Hb remaja putri yang menderita anemia di Madrasah Stanawiyah Islamiyah sebelum dan sesudah diberikan pendidikan teman sebaya (Peer Education).

- Untuk mengetahui perubahan perilaku remaja putri yang menderita anemia di Madrasah Stanawiyah Islamiyah sebelum dan sesudah diberikan pendidikan teman sebaya (Peer Education)

\subsection{Manfaat penelitian}

1. Bagi Madrasah Tsanawiyah Islamiyah

Untuk dijadikan bahan infromasi tentang pentingnya mengkonsumsi asupan zat gizi untuk memenuhi zat besi dalam tubuh serta efek kejadian anemia terhadap prestasi belajar di sekolah sebagai bahan untuk mengembangkan kegiatan kesehatan sekolah dan perbaikan kesehatan.

2. Bagi peneliti

Hasil penelitian ini diharapkan dapat menambah pengetahuan dan pemahaman penulis tentang manfaat asupan zat gizi yang dapat mencegah defisiensi zat besi serta sebagai sarana pembelajaran melakukan penelitian ilmiah sekaligus mengaplikasikan ilmu yang sudah dipelajari, serta sebagai bahan masukan bagi penelitian selanjutnya dan sebagai bahan pembanding untuk pengembangan penelitian sejenis.

\subsection{Hipotesis}

Ho : Tidak ada pengaruh pendidikan teman sebaya (Peer Education) terhadap perilaku remaja putri yang menderita anemia di Madrasah Stanawiyah Islamiyah Jl.Suluh 71 Kota Medan Kota Tahun 2018.

Ha : Ada pengaruh pendidikan teman sebaya (Peer Education) terhadap perilaku remaja putri yang menderita anemia di Madrasah Stanawiyah Islamiyah Jl.Suluh 71 Kota Medan Kota Tahun 2018.

\section{METODE PENELITIAN}

\subsection{Jenis Penelitian}

Jenis penelitian ini adalah quasi eksperimen dengan rancangan one group pre-test post-test design untuk mengetahui pengaruh Pendidikan Teman Sebaya (Peer Education) Terhadap Perilaku Remaja Putri Yang Menderita Anemia Di Madrasah Stanawiyah Islamiyah Jl.Suluh 71 Kota Medan Kota Tahun 2018.

\subsection{Lokasi dan Waktu Penelitian}

Penelitian ini dilakukan di Madrasah Tsanawiyah Islamiyah Jl.Suluh 71 Kota Medan. Kota Tahun 2018.

Penelitian ini berlangsung dari bulan Mei sampai bulan Oktober 2018.

\subsection{Populasi dan Sampel Penelitian}

Populasi dalam penelitian ini adalah seluruh siswi Madrasah Tsanawiyah Islamiyah Jl.Suluh 71 Kota Medan berjumlah 250 orang.

Sampel yang dipilih dalam penelitian ini berjumlah 30 orang berdasarkan teknik consecutive sampling, Artinya sampel dipilih berdasarkan kriteria inklusi dan eksklusi. Kriteria inklusi subjek antara lain menderita anemia ringan, dan bersedia untuk dijadikan sampel penelitian dengan menandatangani lembar persetujuan (informed consent). Peer Educator berjumlah 30 orang yang dipilih dari siswi yang tidak menderita anemia dan pengurus UKS di sekolah tersebut. 


\subsection{Jenis Data dan Metode Pengumpulan Data} a. Data Primer

Data primer adalah data yang didapatkan langsung dari subjek penelitian yang dilakukan dengan cara observasi, pemeriksaan $\mathrm{Hb}$, dan isian kuesioner yang berhubungan dengan penelitian yang dilakukan. Seluruh siswi terlebih dahulu akan diperiksa kadar $\mathrm{Hb}$ nya dan siswi yang menderita anemia akan dijadikan sampel penelitian. Peer Educator berasal dari siswi yang tidak menderita anemia dan pengurus UKS di sekolah tersebut.

\section{b. Data Sekunder}

Data sekunder diperoleh dari profil Madrasah Tsanawiyah Islamiyah Jl.Suluh 71 Kota Medan, data diperoleh dari jurnal penelitian nasional dan Internasional, makalah publikasi, dan hasil penelitian

\section{Metode Pengumpulan data}

1. Tahap permulaan

Pada tahap awal subjek menjalani pretest tentang perilakuuntuk mendapatkan data sebelum diberikan pendidikan teman sebaya (peer education). Selanjutnya, subjek akan diukur kadar Hb awalnya.

2. Tahap Intervensi

Pada tahap ini, subjek selanjutnya diberikan intervensi pendidikan kesehatan selama 2 bulan berupa pendidikan teman sebaya, subjek dalam penelitian ini akan mendapat intervensi suplementasi $\mathrm{Fe}$ satu kali satu hari dan enumerator memantau pola makan sarapannya setiap pagi selama 2 bulan.

3. Tahap Akhir

Pada tahap akhir, subjek menjalani posttest tentang perilaku untuk mendapatkan data sesudah diberikan pendidikan teman sebaya (peer education). Selanjutnya, subjek akan diukur kadar Hb akhirnya.

4. Pengukuran $\mathrm{Hb}$

Pengukuran $\mathrm{Hb}$ dilakukan dengan mensetting ruangan kelas menjadi ruangan pemeriksaan $\mathrm{Hb}$. Pengukuran dilakukan dengan menggunakan Alat Tes Darah Easy Touch GCHb.

\subsection{Definisi Operasional}

\section{Tabel 1 Definisi Operasional Variabel Penelitian}

\begin{tabular}{|c|c|c|c|c|}
\hline Variabel & Cara Ukur & $\begin{array}{c}\text { Alat } \\
\text { Pengukur }\end{array}$ & $\begin{array}{c}\text { Hasil } \\
\text { Pengukur } \\
\text { an }\end{array}$ & Skala \\
\hline $\begin{array}{l}\text { Dependen } \\
\text { Perilaku } \\
\text { Siswi } \\
\text { Yang } \\
\text { menderita } \\
\text { anemia }\end{array}$ & $\begin{array}{l}\text { Peneliti } \\
\text { membagikan } \\
\text { isian } \\
\text { kuesioner } \\
\text { berupa } \\
\text { pertanyaan } \\
\text { perilaku }\end{array}$ & Kuesioner & $\begin{array}{l}\text { Perilaku } \\
\text { positif : } \\
\text { skor }>51 \\
\text { Perilaku } \\
\text { negatif: } \\
\text { Skor }<50\end{array}$ & $\begin{array}{l}\text { Numer } \\
\text { ik }\end{array}$ \\
\hline Kadar Hb & $\begin{array}{l}\text { Sampel darah } \\
\text { subjek } \\
\text { diambil } \\
\text { kemudian } \\
\text { diukur kadar } \\
\text { Hb nya }\end{array}$ & $\begin{array}{l}\text { alat ukur } \\
\text { kadar Hb } \\
\text { digital } \\
\text { merk Easy } \\
\text { Touch } \\
\text { GCHb, } \\
\text { dengan } \\
\text { akurasi } \\
\text { tinggi } \\
\end{array}$ & $\begin{array}{l}\text { Anemia } \\
\text { ringan } 11 \\
\text { gr \% } \\
\text { Anemia } \\
\text { sedang } \\
\text { 8-10 gr\% } \\
\text { Anemia } \\
\text { Berat } \\
<8 \text { gr\% }\end{array}$ & $\begin{array}{l}\text { Numer } \\
\text { ik }\end{array}$ \\
\hline
\end{tabular}

\begin{tabular}{llll}
\hline Pendidikan & Beberapa & Lembar & Baik $=$ jika Ordina \\
Teman & siswa dilatih & observasi & skor $>=1$ \\
Sebaya & sebagai peer & $50 \%$ dan \\
& educator & layak \\
& yang berasal & menjadi \\
& dari & Peer \\
& organisasi & Educator \\
& PMR dan & Kurang $=$ \\
& akan & jika skor $<$ \\
& mendidik & $50 \%$ \\
& temannya & tidak layak \\
& yang & menjadi \\
& menderita & Peer \\
anemia & educator \\
\hline & &
\end{tabular}

\subsection{Pengolahan Data dan Metode Analisis Data}

1. Pengolahan Data

Pada penelitian ini data yang sudah dikumpulkan diolah, sehingga jelas sifat-sifat yang dimiliki data tersebut. Adapun langkah-langkah pengolahan data menurut Saepudin (2011) adalah Editing, Coding dan Tabulating.

\section{Analisis Data}

Analisis data dalam penelitian ini adalah analisis bivariat, untuk melihat perbedaan kadar $\mathrm{Hb}$ dan skor perilaku subjek sebelum dan sesudah intervensi. Data dianalisis dengan menggunakan uji statistik yaitu Paired sample ttest jika data terdistribusi normal, atau uji Wilcoxon jika data tidak terdistribusi normal.

\section{HASIL PENELITIAN}

\subsection{Hasil}

Penelitian tentang Pengaruh Pendidikan Teman Sebaya (Peer Education) Terhadap Perilaku Remaja Putri Yang Menderita Anemia Di Madrasah Stanawiyah Islamiyah Jl.Suluh 71 Kota Medan Kota Tahun 2018 telah dilakukan dengan jumlah responden sebanyak 30 orang. Hasil penelitian perubahan perilaku subjek sebelum dan sesudah diberikan intervensi pendidikan teman sebaya atau disebut Peer Educationdiperoleh menggunakan kuesioner, sedangkan pengukuran kadar $\mathrm{Hb}$ subjek diperoleh berdasarkan hasil pengukuran kadar $\mathrm{Hb}$ menggunakan alatEasy Touch GCHb.

Sampel penelitian ini adalah siswi-siswi yang keseluruhan (100\%) menderita anemia ringan ( $<12$ gr) dan memiliki perilaku yang kurang mengkonsumsi makanan yang kaya akan zat besi.

1. Deskripsi Hasil Penelitian

Distribusi Peer Educator (teman sebaya) penelitian, seperti tersaji dalam tabel 2 dibwah ini.

\begin{tabular}{ccc}
\hline Kriteria & $\boldsymbol{N}$ (jumlah) & $\begin{array}{c}\text { Persentase } \\
(\%)\end{array}$ \\
\hline Baik (50\%) & 30 orang & 100 \\
\hline
\end{tabular}

Berdasarkan tabel 2 diatas diketahui bahwa peer educator yang dipilih berdasarkan tingkat pengetahuan yang baik yaitu sebanyak 30 orang (100\%).

Uji statistik untuk melihat normalitas data menggunakan uji Shapiro-Wilk (p). Nilai p > 0,05 berarti 
data terdistribusi normal, seperti tersaji dalam tabel 4.1b dibawah ini.

Tabel 3

Hasil uji normalitas data

\begin{tabular}{lc}
\hline \multicolumn{1}{c}{ Keterangan } & $\begin{array}{c}\text { Uji Shapiro-Wilk } \\
(\boldsymbol{p})\end{array}$ \\
\hline Kadar Hb sebelum intervensi & $0,095^{*}$ \\
Kadar Hb sesudah intervensi & 0,011 \\
Perilaku sebelum intervensi & 0,008 \\
Perilaku setelah intervensi & 0,035 \\
\hline * terdistribusi
\end{tabular}

*: terdistribusi normal jika $p>0,005$

Berdasarkan tabel diatas diketahui bahwa hampir keseluruhan data yang diperoleh tidak terdistribusi normal oleh karena nilai $\mathrm{p}>0,005$ kecuali variabel kadar $\mathrm{Hb}$ sebelum intervensi yang terdistribusi normal. Dengan demikian analisis bivariat pada penelitian ini menggunakan uji Wilcoxon.

Tabel 4

Uji Wilcoxon perbedaan kadar $\mathrm{Hb}$

\begin{tabular}{cccc}
\hline No & Keterangan & Mean \pm SD & $p$ value \\
\hline 1 & Sebelum & $11,29 \pm 0,44$ & $0,000 *$ \\
2 & Sesudah & $13,42 \pm 0,87$ & \\
*: signifikan jika $p<0,005$ &
\end{tabular}

Gambar 1.

Grafik Rerata Kadar Hb sebelum dan sesudah intervensi

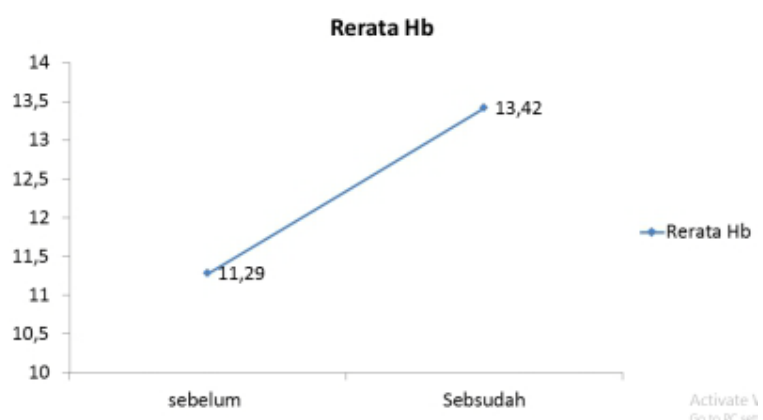

Berdasarkan tabel diatas dapat diketahui terdapat perbedaan yang bermakna sebelum dans sesudah intervensi. $(\mathrm{p}<0,05)$. Rata-rata Kadar Hb subjek meningkat sebesar 2,13 sesudah diberikan intervensi. Dengan demikian dapat dikatakan ada pengaruh pemberian pendidikan teman sebaya (Peer education).

Tabel 5

Uji Wilcoxon perbedaan Perilaku

\begin{tabular}{cccc}
\hline No & Keterangan & Mean \pm SD & p value \\
\hline 1 & Sebelum & $39,67 \pm 8,40$ & $0,000 *$ \\
2 & Sesudah & $74 \pm 7,70$ & \\
*: signifikan jika $p<0,005$ & &
\end{tabular}

Gambar 2

Grafik Rerata Skor Perilaku sebelum dan sesudah intervensi

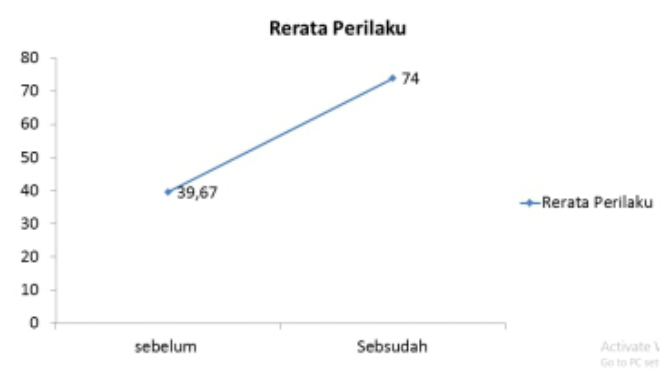

Berdasarkan tabel diatas dapat diketahui terdapat perbedaan yang bermakna sebelum dans sesudah intervensi. $(p<0,05)$. Rata-rata skor penilaian perilaku subjek meningkat sebesar 34,33 sesudah diberikan intervensi. Dengan demikian dapat dikatakan ada pengaruh pemberian pendidikan teman sebaya (Peer education). Pada gambar 2 juga menunjukkan terjadi peningkatan perubahan perilaku subjek yang signifikan sesudah diberikan intervensi.

\subsection{Pembahasan}

Berdasarkan hasil penelitian diketahui terjadi perubahan yang signifikan kadar Hb subjek sebelum dan sesudah diberikan pendidikan teman sebaya. Hasil sesudah perlakukan juga menunjukkan terjadi peningkatan perubahan perilaku kepada siswa-siswi untuk berperilaku mengkonsumsi makanan yang kaya zat besi, sehingga dapat menambah kadar Hb di dalam tubuh. Dari intervensi yang diberikan para siswi tersebut menjadi tahu manfaat dan tujuan mengkonsumsi makanan yang kaya zat besi terlebih pada saat mengalami menstruasi. Peningkatan pengetahuan tersebut berdampak positif pada perbaikan perilaku siswa dalam menjaga pola makannya.

Menurut Azwar (2007), perubahan perilaku dipengaruhi oleh pengalaman pribadi, pengaruh orang yang dianggap penting, lembaga pendidikan dan tingkat pengetahuan. Faktor pengetahuan yang dimiliki responden memegang peranan penting dalam penentuan perilaku yang baik. Maxwell Maltz cit Elfiky (2009) berpendapat bahwa langkah perubahan perilaku terdiri atas tiga tahap. Ketiga tahapan tersebut dibutuhkan waktu minimal 21 hari. Tujuh hari pertama adalah tahapan menanamkan pengetahun untuk memengaruhi pola pikir. Tujuh hari kedua adalah tahapan internalisasi untuk menjadikan suatu perilaku yang telah diketahui sebagai pola sikap atau kebiasaan. Tujuh hari terakhir merupakan tahapan untuk mengubah pola sikap menjadi budaya baru.

Menurut Notoatmodjo (2010) upaya intervensi terhadap faktor perilaku dapat dilakukan melalui dua pendekatan, yaitu pendidikan atau paksaan/tekanan, dan pendekatan pendidikan adalah yang paling tepat sebagai upaya untuk memecahkanmasalah kesehatan masyarakat melalui faktor perilaku.

Remaja putri merupakan salah satu kelompok yang rawan menderita anemia. Oleh karena itu, sasaran program penanggulangan anemia gizi telah dikembangkan 
yaitu mencapai remaja putri SMP, SMA, dan sederajat, serta wanita di luar sekolah sebagai upaya strategis dalam upaya memutus simpul siklus masalah gizi.

Keanekaragaman konsumsi makanan berperan penting dalam membantu meningkatkan penyerapan zat besi di dalam tubuh. Absorpsi besi yang efektif dan efisien memerlukan suasana asam dan adanya reduktor, seperti vitamin C.7 Sifat yang dimiliki vitamin C adalah sebagai promotor terhadap absorpsi besi dengan cara mereduksi besi ferri menjadi ferro.7 Vitamin A memiliki peran dalam hematopoiesis dimana defisiensi vitamin A menyebabkan mobilisasi besi terganggu dan simpanan besi tidak dapat dimanfaatkan untuk eritropoesis.8 Bila asupan makanan kurang maka cadangan besi banyak yang dibongkar. Keadaan seperti ini dapat mempercepat terjadinya anemia. ${ }^{6}$

Penelitian sebelumnya di SMA N 2 Semarang menunjukkan sebesar 47,7\% subjek termasuk dalam kategori baik untuk asupan protein dan sebagian besar subjek memiliki tingkat asupan vitamin A, dan vitamin C di atas kecukupan yaitu masing - masing sebesar 86,2\% dan 30,8\% subjek. Namun, kejadian anemia masih termasuk dalam kategori tinggi, yaitu sebanyak 43,1\% remaja putri memiliki kadar hemoglobin yang rendah dan tergolong anemia. ${ }^{9}$ Kehilangan darah secara kronis juga dapat mengakibatkan terjadinya anemia. Pada wanita, terjadi kehilangan darah secara alami setiap bulannya. Jika darah yang keluar selama menstruasi sangat banyak maka akan terjadi anemia defisiensi besi.

Remaja putri dengan lama menstruasi yang berlangsung lebih dari 8 hari dan siklus menstruasi yang pendek, yaitu kurang dari 28 hari memungkinkan untuk kehilangan besi dalam jumlah yang lebih banyak.10 Anemia dapat menyebabkan lekas lelah, konsentrasi belajar menurun sehingga prestasi belajar rendah dan dapat menurunkan produktivitas kerja. Di samping itu juga menurunkan daya tahan tubuh sehingga mudah terkena infeksi. ${ }^{5}$

Strategi untuk mengatasi masalah anemia pada remaja putri adalah dengan perbaikan kebiasaan makan, fortifikasi makanan dan pemberian suplementasi Fe. Mengubah pola makan dan fortifikasi makanan merupakan strategi jangka panjang yang penting namun tidak dapat diharapkan dapat berhasil dengan cepat.Cara lain adalahdengan memberikan suplementasi $\mathrm{Fe}$ melalui pemberian tablet tambah darah (TTD).

Untuk pencegahan dan pengobatan anemia, suplementasi TTD merupakan cara yang efisien karena mudah didapat, efeknya cepat terlihat, dan harganya relatif murah sehingga terjangkau oleh masyarakat luas. Brabin merekomendasikan program pencegahan anemia dengan suplementasi Fe lebih banyak ditargetkan kepada remaja putri dari pada anak-anak, wanita dewasa atau ibu hamil karena pemberian suplementasi kepada remaja putri akan memberi dampak yang lebih besar pada kesehatan reproduksi dan keberhasilan proses reproduksi dibandingkan dengan suplementasi selama masa hamil saja. Remaja putri merupakan calon ibu yang harus sehat dan tidak anemia, untuk dapat melahirkan bayi yang sehat.

Masalah kepatuhan merupakan kendala utama suplementasi besi harian, dan karena itu alternatif suplementasi mingguan diharapkan dapat mengurangi masalah kepatuhan ini. Tetapi suplementasi mingguan menghadapi masalah dalam hal dosis Fe yang diperlukan untuk meningkatkan kadar hemoglobin dalam darah agar setara dengan suplementasi harian.(24) Sebagai salah satu opsi, dengan demikian, diperlukan penelitian untuk mengetahui keefektifan suplementasi Fe dengan frekuensi di antara mingguan dan harian misalnya dua kali per minggu untuk menilai keefektifan suplementasi terhadap kadar hemoglobin (Hb).

Anemia dapat menyebabkan lekas lelah, konsentrasi belajar menurun sehingga prestasi belajar rendah dan dapat menurunkan produktivitas kerja. Di samping itu juga menurunkan daya tahan tubuh sehingga mudah terkena infeksi Prevalensi anemia yang tinggi dikalangan remaja jika tidak tertangani dengan baik akan berlanjut hingga dewasa dan berkontribusi besar terhadap angka kematian ibu, bayi lahir prematur, dan bayi dengan berat lahir rendah (Agus, ZAN, 2004)

\section{KESIMPULAN DAN SARAN}

\subsection{Kesimpulan}

Berdasarkan hasil penelitian yang didapatkan, dapat ditarik kesimpulan :

a. Ada pengaruh pendidikan teman sebaya (Peer Education) terhadap perilaku remaja putri yang menderita anemia di Madrasah Stanawiyah Islamiyah Jl.Suluh 71 Kota Medan Kota Tahun 2018.

b. Rata-rata Kadar Hb subjek meningkat sebesar 2,13 sesudah diberikan intervensi.

c. Rata-rata skor penilaian perilaku subjek meningkat sebesar 34,33 sesudah diberikan intervensi.

\subsection{Saran}

a. Bagi siswi-siswi di Madrasah Stanawiyah Islamiyah Jl.Suluh 71 Kota Medan Kota Tahun 2018agar membiasakan berperilaku mengkonsumsi makanan yang banyak mengandung Zat besi yang berfungsi meningkatkan kadar $\mathrm{Hb}$ dalam darah sehingga menghambat terjadinya anemia.

b. Diharapkan agar hasil penelitian ini dapat berguna sebagai bahan informasi untuk penelitian selanjutnya sehingga akan membantu para peneliti lain dalam melakukan penelitian.

c. Menambah wawasan bagi penulis tentang pengaruh pendidikan teman sebaya (Peer Education) terhadap perilaku remaja putri yang menderita anemia sehingga dapat mengaplikasikan pada diri sendiri dan lingkungan akan pentingnya menjaga kesehatan saat remaja, salah satu caranya ialah rajin mengkonsumsi makanan yang kaya z 


\section{DAFTAR PUSTAKA}

ACOG, 2006, Menstruation in girls and adolescents: using the menstrual cycles as a vital sign. ACOG Committee Opinion Number 349, 2006.

Afiatna P. Faktor Determinan Gizi pada Remaja Putri di SMA Negeri 2 Semarang [skripsi]. Semarang : Program Studi Ilmu Gizi Fakultas Kedokteran Universitas Diponegoro; 2010.

Agus ZAN. Pengaruh Vitamin C Terhadap Absorpsi Zat Besi pada Ibu Hamil Penderita Anemia. In : MEDIKA Jurnal Kedokteran dan Farmasi. Vol. XXX; 2004.p. 496 - 499.

Al-Sharbatti SS, Al-Ward NJ, Al-Timimi. Anemia Among Adolescent. Saudi Med J. 2003; Vol 24 (2): 189-194. Available from: http://www.smj.org.sa. Cited 2011 March 13.

Arisman MB. Gizi dalam Daur Kehidupan. Jakarta : Penerbit Buku Kedokteran EGC; 2002. p.145147.

Bakta IM, Pendekatan Terhadap Pasien Anemia. In : Sudoyo AW, Bambang Setiyohadi, Idrus Alwi, Marcellus Simadibrata K, Siti Setiati, editors. Buku Ajar Ilmu Penyakit Dalam. edisi IV, jilid II. Jakarta Pusat: Pusat Penerbitan Ilmu Penyakit Dalam FK UI; 2006.p.622-623.

Baral KP, Onta SR. Prevalence of Anemia Amongst Adolescents in Nepal : a Community Based Study in Rural and Urban Areas of Morang Distric. Nepal Med Coll J. 2009; Vol. 11(3):179 - 182. Available from : http://www.nmcth.edu. Cited 2011 March 20.

Gallagher ML. The Nutrients and Their Metabolism. In : Mahan LK, EscottStump S. Krause's Food, Nutrition, and Diet Therapy. 12th edition. Philadelphia: Saunders; 2008.
Hidayat, A. Aziz Alimul. 2007. Metode Penelitian Kebidanan \& Teknik Analisis Data. Jakarta : Salemba Medika.

National Anemia Action Council. Anemia in Adolescents : The Teen Scene. 2009 January 14 . Available from: http://www.anemia.org. Cited 2011 March 9.

Notoatmodjo, S. 2010. Promosi Kesehatan: Teori dan Aplikasi. Jakarta: Rineka Cipta.

Notoatmodjo, Soekidjo. 2003. Ilmu Kesehatan Masyarakat. Jakarta : Rineka Cipta.

Notoatmodjo, Soekidjo. 2003. Metode Penelitian Kesehatan. Jakarta: Rineka Cipta.

Notoatmodjo, Soekidjo. 2003. Pendidikan dan Perilaku Kesehatan. Jakarta : Rineka Cipta.

Sandra, dkk, Pengaruh suplementasi zat besi satu dan dua kali per minggu terhadap kadar hemoglobin pada siswi yang menderita anemia. Jurnal Universa Medicina Vol 24 No 4.

Subagio HW. Hubungan antara Status Vitamin A dan Seng Ibu Hamil dengan Keberhasilan Suplementasi Besi [dissertation]. In: Purwaningsih E. Bunga Rampai Topik Gizi. Seri 1. Semarang : Badan Penerbit UNDIP;2008.

Tim Penulis Poltekkes Depkes Jakarta I. Kesehatan Remaja Problem dan Solusinya. Jakarta: Penerbit Salemba Medika;2010.p.25-26

Yunarsih, dkk, Hubungan Pola Menstruasi Dengan Kejadian Anemia Pada Remaja Putri Kelas VII SMPN 6 Kediri. Jurnal Ilmu Kesehatan Vol.3 No. 1 Nopember 2014. 